Ecclesia. Studia z Dziejów Wielkopolski t. 13 (2018)

doi: $10.14746 /$ e.2018.13.8

ORCID: 0000-0002-5725-3880

\author{
ADAM PRZYBECKI \\ Uniwersytet im. Adama Mickiewicza w Poznaniu \\ Wydział Teologiczny
}

\title{
Duszpasterstwo Kościoła w Polsce wobec postępującego pluralizmu społeczno-kulturowego
}

Wraz ze zmianą sytuacji społeczno-politycznej, która dokonała się w Polsce dzięki przełomowym wydarzeniom 1989 roku, nastąpiło również poszerzenie pola pluralizmu w życiu publicznym. Pluralizmem w aspekcie społeczno-kulturowym najczęściej zajmują się socjologowie, którzy za cel stawiają sobie zwrócenie uwagi i wyjaśnienie pewnych zjawisk społecznych i kulturowych, występujących zwłaszcza w społeczeństwach o wysokim stopniu rozwoju. Chodzi tutaj nie tylko o zwykłą wielość czy różnorodność, ale także o specyficzną sytuację, rozumianą jako swoista konkurencja i współzawodnictwo „między autonomicznymi podmiotami życia społecznego w zakresie podstawowych celów, wartości i dążeń"1. Tak więc pluralizm ma miejsce tam, gdzie nie istnieje monopol i dominacja jednych systemów nad innymi.

Zwraca się często uwagę, że nie sposób precyzyjnie określić momentu pojawienia się pluralizmu społeczno-kulturowego, na którego powstanie i rozwój miało wpływ wiele czynników. Odwołując się do przemyśleń Petera Bergera i Thomasa Luckmanna, podkreśla się, że ,globalną historyczną siłą prowoku-

${ }^{1}$ W. Piwowarski, Pluralizm społeczno-kulturowy a religia, „Roczniki Nauk Socjologicznych, t. VIII (1980), s. 105. Szerzej na ten temat - B. Stubenrauch, Pluralismus statt Katholizität. Gott, das Christentum und die Religionen, Regensburg 2017; P.M. Zulehner, Verbuntung. Kirchen im weltanschaulichen Pluralismus. Religion im Leben der Menschen 1970-2010, Ostfildern 2011; B. Dziri, A. Dziri (Hg.), Aufbruch statt Abbruch. Religionen und Werte in einer pluralen Gesellschaft, Freiburg im Br. 2018; M. Rhonheimer, Christentum und säkularer Staat. Geschichte - Gegenwart - Zukunft, Freiburg im Br. 2014³; H. Dreier, Staat ohne Gott. Religion in der säkularen Moderne, München 2018; H.M. Heinig, Säkularer Staat - viele Religionen. Religionspolitische Herausforderungen der Gegenwart, Hamburg 2018; K. Viertbauer, F. Wegscheider (Hg.), Christliches Europa? Religiöser Pluralismus als theologische Herausforderung, Freiburg im Br. 2017. 
jącą pluralizm jest sekularyzacja. W konsekwencji zjawisko pluralizmu łączą $\mathrm{z}$ religią szeroko rozumianą, a więc zarówno z religią jako instytucją (kościoły), jak i z religią jako światopoglądem jednostki (religijność instytucjonalna czy pozainstytucjonalna). Znajduje to wyraz w sekularyzacji, przez którą rozumieją stopniowe wyzwalanie się (autonomizację) społecznych sektorów spod panowania religijnych instytucji i systemów znaczeń"2.

Zgodnie z podanym określeniem, proces sekularyzacji oznacza zanikanie dominacji religii instytucjonalnej w strukturze i kulturze społeczeństwa, z drugiej - współzawodnictwo między różnymi systemami znaczeń reprezentowanych przez różne podmioty społeczeństwa. Według wcześniej wspomnianych autorów „sekularyzacja ab initio zawiera pluralizm i występuje tam, gdzie istnieje możliwość przynajmniej minimalnego wyboru w postaci powiedzenia «tak» lub «nie» w stosunku do panującej tradycji religijnej"3.

Pluralizm społeczny lub strukturalny odnoszony jest do społeczeństwa o strukturze złożonej, kompleksowej, charakteryzującej się dużym zróżnicowaniem społecznym, będącej przeciwieństwem społeczeństwa o prostej konstrukcji, które identyfikowane jest ze społeczeństwem pierwotnym i preindustrialnym. To ostatnie utożsamia się z małym zróżnicowaniem społecznym, wspólnotami koncentrycznymi i wielofunkcyjnymi, a także $\mathrm{z}$ ułatwiającą i wspomagającą znaczący zakres konsensusu homogeniczną kulturą. Pluralizm społeczny lub strukturalny próbuje się określać ,jako sytuację, w której jednostki ludzkie, grupy i instytucje społeczne ze względu na symetryzację, autonomizację i specjalizację społeczeństwa, pozostają we wzajemnej konkurencji i współzawodnictwie w preferowaniu, legitymizowaniu i urzeczywistnianiu własnych systemów znaczeń. $Z$ tego określenia widać, że ten rodzaj pluralizmu pozostaje $\mathrm{w}$ ścisłym powiązaniu $\mathrm{z}$ innym, mianowicie $\mathrm{z}$ pluralizmem kulturowym"4.

Z kolei pluralizm kulturowy, który, jak wspomniano, pozostaje w ścisłym związku z pluralizmem społecznym, jest właściwie innym wymiarem tego samego zjawiska. Odróżnia je sposób upowszechniania się w zależności od tego, czy dotyczy płaszczyzny struktury społecznej, czy szeroko rozumianej płaszczyzny kultury. W tym wypadku chodzi m.in. o takie kwestie, jak sens życia, świat wartości i wzory zachowań. Socjologowie ten rodzaj pluralizmu opisują jako „sytuację, w której występuje konkurencja i współzawodnictwo w instytucjonalnym porządku ogólnych znaczeń, dotyczących życia codziennego. Konkurencja i współzawodnictwo mają miejsce tam, gdzie brak konsensusu homogeniczności i monopolu światopoglądowego. Wówczas jednostki

\footnotetext{
${ }^{2}$ W. Piwowarski, Pluralizm społeczno-kulturowy a religia, s. 106.

${ }^{3}$ Tamże.

${ }^{4}$ Tamże, s. 109.
} 
lub grupy ludzkie mogą rywalizować na «rynku światopoglądowym» w zakresie preferowania własnych światopoglądów"5. Ta sytuacja inicjuje proces przemian, który ostatecznie prowadzi do indywidualizacji i prywatyzacji religii w przestrzeni społeczeństwa złożonego, co oznacza utratę obiektywnego statusu religii w indywidualnej świadomości. Religia staje się kwestią wyboru i osobistego przekonania.

Podejmując rozważania związane z ciągle postępującym procesem pluralizmu społeczno-kulturowego i konsekwencjami, jakie wynikają z tego dla pastoralnej posługi Kościoła w Polsce, spróbujemy najpierw opisać ten proces, a następnie przybliżyć główne myśli nauczania Kościoła odnośnie do omawianego zjawiska, aby na koniec sformułować propozycje, które mogą stać się impulsem dla polskiego duszpasterstwa.

\section{Rozwój zjawiska w Polsce}

W popularnym przekazie można dość często spotkać się ze stwierdzeniem, że problem pluralizmu społeczno-kulturowego w Polsce pojawił się dopiero po upadku komunizmu wraz z rozwijającą się demokracją i w warunkach gospodarki rynkowej. Tymczasem w 1980 r. Władysław Piwowarski stawiał pytanie, w jakim stopniu w warunkach ówczesnego społeczeństwa polskiego występował pluralizm społeczno-kulturowy. Dwa lata później, w 1982 r., zwracał uwagę, że „w Polsce już od dłuższego okresu czasu ujawnił się pluralizm kulturowy, a ostatnio także pluralizm społeczny"6. Dla socjologa religii interesujące było ustalenie, czy przemiany kościelno-religijne w Polsce, pozostającej pod rządami marksistowskiej partii, uwarunkowane były przede wszystkim ,wpływem dwóch systemów oficjalnych - kościelnego i państwowego, a ściślej, podejmowanymi przez te systemy działaniami (duszpasterstwo i laicyzacja kierowana), czy też wpływem procesu sekularyzacji, czyli laicyzacji spontanicznej, ciągle nasilającej się w okresie powojennym ze względu na intensywną industrializację i urbanizację kraju"7. Oczywiście, w państwie socjalistycznym, które miało charakter monolityczny i zmierzało do podporządkowania centralnym ośrodkom dyspozycyjnym wszelkich przejawów życia

5 Tamże, s. 113. Na temat pluralizmu społeczno-kulturowego patrz także: J. Mariański, Religia i Kościół między tradycją i ponowoczesnością. Studium socjologiczne, Kraków 1997, s. 80-97 i 212-232; A. Kasperek, Czy pluralizm religijny prowadzi do sekularyzacji? Socjologiczna glosa w sprawie polemiki Steve'a Bruce'a z Peterem Bergerem, [w:] Religijność i duchowość - dawne i nowe formy, red. M. Libiszowska-Żółtkowska i S. Grotowska, Kraków 2010, s. 131-144.

${ }^{6}$ W. Piwowarski, Miejsce i rola Kościoła ludowego w spoteczeństwie polskim, „Przegląd Powszechny", nr 1-2, 1982, s. 65.

${ }^{7}$ W. Piwowarski, Pluralizm społeczno-kulturowy a religia, s. 113. 
oraz aktywności obywateli, trudno mówić o pluralizmie społecznym (strukturalnym). Brak interakcji o charakterze poziomym prowadził do ukształtowania się pewnego rodzaju społeczeństwa masowego. Fakt ten dobrze rozeznało ówczesne duszpasterstwo, które opierając się na doświadczeniach dominującego wtedy w Polsce modelu Kościoła ludowego, inicjowało akcje o szerszym zasięgu w ramach tzw. duszpasterstwa masowego. Na tamtym etapie okazało się to możliwe z powodu braku pluralizmu społecznego. $Z$ tego m.in. powodu, tzw. laicyzacja kierowana, którą sterowała rządząca władza i jej sojusznicy, nie przyniosła w Polsce większych sukcesów. Aktywność bowiem laickich instytucji propagandowych w znacznej mierze osłabiana była przez Kościół, kierujący swą działalność w stronę całego społeczeństwa ${ }^{8}$.

Natomiast odmiennie wówczas jawiła się sprawa pluralizmu kulturowego, określanego jako możliwość konkurencji między światopoglądami. Rozwijał się on głównie pod wpływem procesu sekularyzacji, określanego także laicyzacją spontaniczną, a także „,innych czynników współwystępujących, jak industrializacja, urbanizacja, racjonalizacja itp. Trzeba dodać, że ujawnia się on w sferze świadomości jednostek ludzkich, przy czym w społeczeństwach zachodnich znajduje wsparcie w wyspecjalizowanych subsystemach i instytucjach społecznych"”. Podkreślić należy, że w tym czasie nie miał on w Polsce instytucjonalnego wsparcia wskutek słabości pluralizmu społecznego, czego wyrazem był fakt, że postawy światopoglądowe obywateli wykazywały słaby lub w ogóle nieobecny związek z instytucjami religijnymi i państwowymi. Jednak w początku lat osiemdziesiątych XX w. pluralizm kulturowy w Polsce zaczął być wyraźniej artykułowany, poszukiwał także instytucjonalnego wsparcia. Okazało się to możliwe dzięki oddolnie awansującym się wtenczas ruchom społeczno-politycznym, np. „Solidarność”. Sytuacja spontanicznego „obudzenia” społecznego świadczyła o ujawnieniu się ,pewnych wartości i postaw, które tkwiły w społeczeństwie i nie znajdowały warunków ujawnienia się na zewnątrz w sferze życia publicznego. Z kolei to «instytucjonalne wsparcie», o którym wspomniano, jest dowodem świadczącym o zaistnieniu pluralizmu społecznego" 10 .

Oczywiście gwałtowny rozwój pluralizmu społeczno-kulturowego nastąpił w Polsce po upadku systemu komunistycznego. W warunkach rozwijającej

\footnotetext{
${ }^{8}$ Por. W. Piwowarski, Miejsce i rola Kościoła ludowego..., s. 65-66.

${ }^{9}$ Tamże, s. 66.

10 Tamże, s. 67. Autor zwracał uwagę, że wskutek zaistniałej sytuacji, także w Kościele katolickim w Polsce rodzi się pewien pluralizm „w postaci powstawania różnych substruktur (ruchów i wspólnot) oraz religijności selektywnej, nie mieszczącej się ani w religijności ludowej, tradycyjnej, ani w religijności instytucjonalnej, kościelnej. Pluralizm ten może się pogłębiać, gdyby nastąpił z jednej strony wzrost dobrobytu materialnego (konsumpcyjnego stylu życia), a z drugiej, wzrost procesów laicyzacji (zwłaszcza spontanicznej)" (s. 67).
} 
się gospodarki rynkowej i demokratycznego systemu polityczno-społecznego rozpoczął się proces poszukiwania nowych zasad, które wyznaczałyby kształt życia społecznego. Pociągało to za sobą zasadniczą przebudowę struktur społecznych, politycznych i gospodarczych polskiego społeczeństwa, a także postępujący pluralizm, który stał się wprost zasadą organizacji jego życia. Te fakty wpływają na kształtowanie świadomości poszczególnych osób, chcących coraz bardziej widzieć siebie nie jako zbiór jednostek, ale jako skupisko wielu grup, stowarzyszeń, instytucji, organizacji, do których przynależność ma charakter wolny i wynika z ich indywidualnej decyzji. Wraz z rozwojem tej świadomości i utrwalaniem się nowych struktur, jak zwracają na to uwagę socjologowie, następuje radykalizacja pluralizmu społecznego i kulturowego. Zgodnie z charakterystycznym dla społeczeństwa pluralistycznego zjawiskiem, pojawia się, także w Polsce, ,wiele konkurencyjnych grup społecznych, częściowo przenikających się, częściowo niezależnych od siebie. Ich liczba jest właściwie nieograniczona, na miejsce jednych powstają drugie. Cele grupowe mogą być ukierunkowane bardziej «do wewnątrz» lub bardziej «na zewnątrz», bardziej na dobro swoich członków lub bardziej na wspomaganie interesów środowiska. Wszystkim grupom społecznym przysługuje daleko idąca samodzielność i autonomia. Jednostka nie jest skazana na jeden zamknięty system aksjologiczny, lecz jest konfrontowana z różnorodnymi możliwościami stylów życia i ocen postępowania"11. Powoduje to niekiedy osłabienie roli i wpływu dotychczas ogólnie obowiązujących norm i wartości moralnych, a w pewnych sytuacjach może prowadzić do ich znacznego ograniczenia.

Warto zwrócić uwagę, że pluralizacja życia społecznego pociąga za sobą pewien rodzaj jego relatywizacji i powoduje często, że osoba „nie wie, jak należy myśleć, jak należy działać, w końcu kim ona właściwie jest" ${ }^{\prime 2}$. To doświadczenie stało się m.in. udziałem sporej liczby katolików, zwłaszcza w początkach rodzącej się w Polsce demokracji. Przyzwyczajeni dotychczas do życia $\mathrm{w}$ jednorodnej społeczności religijnej, konfrontowani jedynie z wrogą im marksistowską władzą i niestający wobec konieczności uzasadnienia swoich osobistych wyborów, nie potrafili odnaleźć się pośród pojawiających się nagle licznych propozycji ideowo-religijnych. Socjologowie religii w 2011 r. odnotowywali na podstawie przeprowadzonych badań, że zdają się one wskazywać na oznaki słabnącej siły moralnej Kościoła katolickiego w Polsce. Równocześnie stwierdzali, że ,procesy sekularyzacyjne w Polsce nie są jeszcze zbyt zaawansowane, a katolicyzm nie jest tak silny, jak mniemają jego obrońcy, ani tak słaby, jak opisują to jego krytycy. Jest on niewątpliwie wewnętrznie zróżnicowany i wielosektorowy. Katolicyzm polski jest jakby «wielogłosowy»,

\footnotetext{
${ }^{11}$ J. Mariański, Religia i Kościót między tradycją..., s. 80-81.

${ }^{12}$ Tamże, s. 86.
} 
może nawet wydawać się swoistą fortecą. Z zewnątrz instytucjonalny gmach Kościoła wydaje się nietknięty (np. autodeklaracje wyznaniowe i religijne, uczestnictwo w praktykach religijnych), jeżeli przyjrzeć się jednak dokładniej, to można dostrzec poważne rysy sięgające aż do fundamentów jego struktury, zwłaszcza w dziedzinie moralności"13.

W publikacjach socjologicznych zauważa się, że Kościół katolicki w Polsce próbuje się bronić przed negatywnymi skutkami postępującego pluralizmu społeczno-kulturowego i związanymi z nim procesami liberalizacji, przede wszystkim poprzez niedostosowywanie ,swoich wymagań wobec wierzących i aprobowanych form religijności do subiektywnych potrzeb ludzi współczesnych, kosztem wierności tradycji. Stara się utrzymać swoją dotychczasową tożsamość Kościoła masowego i zarazem religijność kościelną w świadomości i zachowaniach wiernych. Niemniej i w społeczeństwie polskim można zaobserwować procesy prywatyzacji czy indywidualizacji, w których akcentuje się osobisty kontakt z Bogiem, niezapośredniczony przez Kościół"14. Pozostaje jednak otwarte pytanie, w jakim stopniu działania te w warunkach wyłaniającego się społeczeństwa pluralistycznego, będą w stanie powstrzymać zmieniającą się religijność i więzi z Kościołem. To prawda, na co zwracano uwagę w pierwszych latach XXI w., że w Polsce w warunkach transformacji ustrojowej nie dokonał się gwałtowny rozpad dotychczasowych struktur religijno-kościelnych, ale równocześnie zauważano rodzące się nowe zróżnicowania religijne. Jednocześnie nie wykluczano, że ,przyhamowanie procesów sekularyzacyjnych jest przejściowe, należy liczyć się w przyszłości z galopującą sekularyzacją i wszechstronną laicyzacją" ${ }^{15}$. Najnowsze wyniki badań socjologicznych z ostatnich lat zdają się wskazywać na słuszność tej ostatniej hipotezy. Najbardziej proces ten można zauważyć wśród młodego pokolenia Polaków ${ }^{16}$.

13 J. Mariański, Katolicyzm polski. Ciagłość i zmiana. Studium socjologiczne, Kraków 2011, s. 71. Autor dalej rozwija ten ostatni wątek, stwierdzając: „wiele wskazuje na to, że załamanie się kondycji moralnej społeczeństwa polskiego nastąpiło już wcześniej (swoiste przesunięcie w uznawanych wartościach). W latach dziewięćdziesiątych pewne zjawiska uległy jedynie pogłębieniu i upowszechnieniu. Twierdzenie, że przed 1989 rokiem moralność Polaków miała chrześcijański wymiar, jest przesadą, bardziej mitem i stereotypem niż rzeczywistością. Współcześnie zaznacza się prawdopodobnie proces polaryzacji i «konscientyzacji» postaw i zachowań moralnych. Wydaje się powoli zwiększać krąg ludzi świadomie i zdecydowanie opowiadających się za doktryną moralną Kościoła i jeszcze szybciej krąg ludzi świadomie kwestionujących poszczególne elementy tej doktryny («jestem katolikiem, ale...»). Ci pierwsi starają się na swój sposób realizować wezwanie Jana Pawła II z dnia 6 czerwca 1991 roku w Olsztynie do kształtowania nowego stylu bycia katolikiem, ci drudzy rozwijają jakieś elementy ponowoczesnej moralności” (s. 71-72).

14 Tamże, s. 79.

15 J. Mariański, Kościól katolicki w Polsce a życie społeczne. Studium socjologiczno-pastoralne, Lublin 2005, s. 95.

${ }^{16}$ Por. K. Pacewicz, Polska globalnym liderem... w spadku religijności, „OKO.press”, 19 czerwca 2018 - https://oko.press/polska-globalnym-liderem-w-spadku-religijnosci [dostęp: 20.09.2018]. 


\section{Zagadnienie pluralizmu w społecznym nauczaniu Kościoła}

Nauka społeczna Kościoła w odniesieniu do problematyki pluralizmu podlegała $\mathrm{w}$ ostatnim stuleciu procesowi ewolucji, przede wszystkim pod wpływem zmian zachodzących w życiu społecznym. Proces ten zmierzał ostatecznie do sformułowania konkretnych zasad moralno-społecznych, a także dostarczenia nowych inspiracji, które uwzględniałyby istniejące różnice kulturowe, społeczne czy polityczne. Kwestia pluralizmu postrzegana jest w niej jako jedno z trzech wielkich wyzwań, które podejmowane są przez współczesne pokolenia. Przedstawiana zostaje obok wyzwania, jakim dla współczesnej ludzkości jest „sama prawda o bycie, jakim jest człowiek” oraz wyzwania, jakie stanowi globalizacja. Przedmiot trzeciego wyzwania stanowi ,rozumienie i praktyczne podejście do pluralizmu oraz różnic na wszystkich poziomach: myślenia, moralnych wyborów, kultury, przynależności religijnej, filozofii ludzkiego i społecznego rozwoju” ${ }^{17}$. Mimo wspomnianych różnic „Kościół $\mathrm{z}$ jednej strony akceptuje pluralizm w sferze życia społeczno-politycznego i gospodarczego, ale zarazem broni swojej tożsamości ugruntowanej na niezmiennych prawdach wiary i wartościach moralnych" ${ }^{18}$. Uznanie współczesnego zróżnicowania wraz z cechującą go dynamiką i możliwością pogłębiania się tego procesu, w świetle nauki społecznej Kościoła nie oznacza, że pluralizm jest „wartością samą w sobie, ale staje się nią wówczas, gdy prowadzi do wzbogacenia o nowe wartości, gdy pluralizmowi towarzyszy możliwość poznania różnych rozwiązań, dialog i związana z nim gotowość do wysłuchiwania innych, otwarcie na ich poglądy i gotowość do uznania ich racji, wzajemny szacunek i tolerancja, a zwłaszcza współpraca w zakresie określonym przez dobro wspólne" ${ }^{19}$. Jak się podkreśla, dobro wspólne zależy od zdrowego

Autor odnotowuje, że „odsetek młodych, którzy modlą się codziennie, jest poniżej europejskiej średniej. Wbrew przekonaniu, że Polska jest bastionem chrześcijaństwa, postępuje błyskawiczna laicyzacja. Pomimo ogromnej obecności religii w życiu publicznym i szkołach, różnica religijności między młodszymi a starszymi Polkami i Polakami jest największa [...]. Niezależna amerykańska firma badawcza Pew Research Center porównała religijność ludzi przed czterdziestką i po czterdziestce w 108 państwach na całym świecie. Wyniki są jednoznaczne: młodzi są mniej religijni niż starsi, a w mniej więcej połowie państw nastąpił spadek religijności. Ze wszystkich przebadanych państw, największy spadek religijności - z generacji na generację - nastąpił w Polsce" (tamże); zob. także: CBOS, Religijność Polaków i ocena sytuacji Kościoła katolickiego. Komunikat z badań nr 147/2018 (listopad 2018) - https://www.cbos.pl/SPISKOM.POL/2018/K_147_18.PDF [dostęp: 10.12.2018].

${ }^{17}$ Papieska Rada Iustitia et Pax, Kompendium nauki społecznej Kościoła, Kielce 2005, pkt 16, s. 9.

${ }^{18}$ B. Drożdż, W. Przygoda, Pluralizm społeczno-kulturowy, [w:] Leksykon teologii pastoralnej, red. R. Kamiński, W. Przygoda, M. Fiałkowski, Lublin 2006, s. 624.

${ }^{19}$ J. Wagner, Pluralizm, [w:] Stownik katolickiej nauki społecznej, red. W. Piwowarski, Warszawa 1993 , s. 130. 
pluralizmu społecznego, przypominając że „liczne społeczności powołane są do tworzenia jednolitej i harmonijnej tkanki, w obrębie której każda z nich będzie mogła zachowywać i rozwijać swoje oblicze oraz autonomię. Niektóre z nich, jak rodzina, wspólnota obywatelska, czyli państwo, a także wspólnota religijna, bardziej bezpośrednio odpowiadają najgłębszej naturze człowieka, inne zaś wywodzą się z wolnego wyboru" ${ }^{20}$. Uzasadnieniem kościelnego zaangażowania na rzecz pluralizmu społecznego jest przekonanie, że zmierza ono do „osiągnięcia bardziej adekwatnej realizacji dobra wspólnego i samej demokracji, na podstawie zasady solidarności, pomocniczości i sprawiedliwości"21.

Jan Paweł II zwracał uwagę, że pluralizm pojmowany jako różnorodność i wielość docenia ludzką wolność, ale jej nie absolutyzuje. Jej granicę w pluralizmie wyznacza odniesienie do obiektywnej prawdy. Brak jej uznania prowadzi do pluralizmu relatywistycznego i permisywnego. Dlatego w encyklice Fides et ratio zwraca uwagę na szerzący się bezkrytyczny pluralizm, opierający się na założeniu, ,że wszystkie opinie mają równą wartość: jest to jeden z najbardziej rozpowszechnionych przejawów braku wiary w istnienie prawdy, obserwowanego we współczesnym świecie. Od takiej postawy nie są wolne także pewne koncepcje życia pochodzące ze Wschodu: odbierają one bowiem prawdzie charakter absolutny, wychodząc z założenia, że objawia się ona $\mathrm{w}$ równej mierze $\mathrm{w}$ różnych doktrynach, nawet wzajemnie sprzecznych. W takiej perspektywie wszystko zostaje sprowadzone do rangi opinii" 22 . Pozbawiony odniesienia do obiektywnej prawdy pluralizm prowadzi do osobowego kryzysu i sprawia, że człowiek traci zdolność podejmowania decyzji zgodnej z dobrem wspólnym. Kształtuje także przekonanie, że współczesne pluralistyczne społeczeństwo „,powinno pozostawiać każdej osobie pełną autonomię $w$ dysponowaniu życiem własnym oraz życiem tego, który się jeszcze nie narodził: nie jest zatem rzeczą prawa dokonywanie wyboru pomiędzy różnymi poglądami moralnymi, a tym bardziej nie powinno ono dążyć do narzucenia jednej szczególnej opinii na niekorzyść innych"23.

Sytuacja współczesnego człowieka, który ukształtowany został szczególnie przez obojętność religijną i niewiarę w zdolność rozumu do poznania obiektywnej i uniwersalnej prawdy, wymaga zdolności właściwego rozeznania rzeczywistości. Dlatego Jan Paweł II zwracał uwagę, że „współczesne zjawisko daleko posuniętego pluralizmu, nie tylko w społeczeństwie świeckim, lecz również w samej wspólnocie Kościoła, wymaga szczególnej zdolności

\footnotetext{
${ }^{20}$ Papieska Rada Iustitia et Pax, Kompendium..., pkt 151, s. 97.

${ }^{21}$ Tamże, pkt 417, s. 272.

${ }^{22}$ Jan Paweł II, Encyklika Fides et ratio, Watykan 1998, pkt 5, s. 10-11.

${ }^{23}$ Jan Paweł II, Encyklika Evangelium vitae, Watykan 1995, pkt 68, s. 129.
} 
krytycznego rozeznawania rzeczy. Jest to kolejny motyw uzasadniający konieczność bardzo głębokiej formacji intelektualnej”24.

Dzisiaj coraz częściej w życiu społeczeństw obecny jest pluralizm kulturowy. Zakłada on zaufanie i wzajemny szacunek tych, którzy żyją obok siebie. Kościół popiera wszelką współpracę w tej dziedzinie, kształtuje sumienia swoich członków w duchu szacunku dla każdego człowieka oraz pluralizmu. Przestrzega jednak przed pewnego rodzaju relatywizmem kulturowym, lansującym pluralizm etyczny, „który sankcjonuje dekadencję rozumu oraz rozkład zasad naturalnego prawa moralnego. Pod wpływem tej tendencji nierzadko niestety pojawiają się w deklaracjach publicznych tezy, że tego rodzaju pluralizm etyczny jest warunkiem demokracji” ${ }^{25}$.

Jak zauważył Jan Paweł II w Orędziu na Światowy Dzień Migranta i Uchodźcy z 2005 r., w sytuacji, w której coraz częściej przychodzi nam żyć w środowiskach pluralistycznych ,konieczne jest dążenie do właściwej równowagi między zachowaniem własnej tożsamości a uznaniem tożsamości innych. Należy bowiem akceptować istnienie w danym kraju uprawnionej wielości kultur, dbając, aby było to zgodne z ochroną ładu, od którego zależy pokój społeczny i wolność obywateli”. Równocześnie pojawia się ,potrzeba dialogu między ludźmi różnych kultur, który nie jest jedynie wyrazem tolerancji, ale rodzi sympatię. Jeśli społeczności migrantów i ludność miejscowa tylko żyją obok siebie, prowadzi to zwykle do wzajemnego zamknięcia się kultur, albo też do ustanowienia między nimi relacji czysto zewnętrznych, sprowadzających się wyłącznie do tolerancji. Należałoby więc dążyć do tego, aby kultury wzbogacały się nawzajem. Aby to było możliwe, winny otwierać się na siebie, poznawać się, okazywać sobie autentyczne zrozumienie i życzliwość’26.

\section{W perspektywie przyszłości}

Rozwijający się pluralizm społeczno-kulturowy w Polsce stanowi wielkie wyzwanie dla przyszłości Kościoła lokalnego, a także duszpasterstwa i podstawowych jego struktur. Procesowi temu towarzyszy powolny proces laicyzacji wielu środowisk społecznych, choć w świadomości zbiorowej Polaków

${ }^{24}$ Jan Paweł II, Adhortacja apostolska Pastores dabo vobis, „L'Osservatore Romano”, wyd. polskie, nr 3-4, 1992, pkt 51, s. 40-41.

25 Kongregacja Nauki Wiary, Nota doktrynalna o niektórych aspektach działalności i postępowania katolików $w$ życiu politycznym, Watykan 2002, II,2 - http://www.vatican.va/ro man_curia/congregations/cfaith/documents/rc_con_cfaith_doc_20021124_politica_pl.html [dostęp: 10.12.2018].

${ }^{26}$ O zachowanie własnej tożsamości i uznanie tożsamości innych (2005), [w:] Jan Paweł II, Orędzia na Światowy Dzień Migranta i Uchodźcy 1985-2005, opr. W. Necel, Poznań 2009, s. 141. 
religia zinstytucjonalizowana ciągle odgrywa znaczącą rolę. Jednakże „religijność potoczna (środowiskowa) koncentruje się przede wszystkim na aspektach rytualno-kultowych, nie zawsze pomaga zająć odpowiednią postawę w życiu codziennym, uczynić ją bardziej chrześcijańską i przepojoną humanizmem płynącym z Ewangelii”'27. Jest to jednocześnie religijność niespójna i mocno zróżnicowana, co sprawia, że staje się ,podatna na wpływy ideologiczne, pochodzące z różnych kręgów kulturowych" 28 . Już w latach dziewięćdziesiątych przeprowadzone analizy badań socjologicznych potwierdzały częściowo tezę, że ,autorytet moralny Kościoła w Polsce - podobnie jak w innych krajach - ma w pewnym sensie «abstrakcyjny» charakter, tzn. jest uznawany jako instancja moralna dla innych («nie dla mnie») i nieobowiązujący we wszystkich dziedzinach życia (np. w sferze moralności seksualnej). Osłabienie autorytetu Kościoła pociąga za sobą na ogół zmniejszanie się także moralnego konsensusu" 29 .

W tej sytuacji ważna jest najpierw odpowiedź na pytanie, które sformułował jeden z socjologów religii, a dotyczące podstawowego kierunku duszpasterstwa - „czy w procesie demokratyzacji społeczeństwa polskiego Kościół utrzyma swoją pozycję Kościoła ludowego, masowego, o rozbudowanych funkcjach społecznych, czy też pod wpływem sekularyzacji spontanicznej i pluralizmu społecznego będzie się przeobrażał podobnie jak w demokracjach zachodnich?"30. Wydaje się, że skoro religijność polska w znacznej mierze jest religijnością ludową, to zadaniem duszpasterstwa powinno być podtrzymywanie tego rodzaju religijności. Wymaga to oczywiście od duszpasterstwa masowego równoległego wysiłku systematycznego pogłębiania (socjalizacji religijnej), przede wszystkim poprzez aktywność wspólnot, różnego rodzaju grup formacyjnych i ruchów religijnych, działających zarówno w ramach parafii, jak i poza jej terytorium ${ }^{31}$. Trudno bowiem, zgodnie z prawami socjologii, aby coś było równocześnie masowe i niepowierzchowne.

Charakterystyczna dla społeczeństwa pluralistycznego konkurencyjność na płaszczyźnie światopoglądowej, w pewnych sytuacjach może prowadzić do zmiany modelu religijności i osłabienia pozycji społeczno-moralnej Kościoła. Dlatego tak ważny jest sposób realizacji podstawowej misji ewangelizacyjnej, uwzględniający nowe warunki społeczno-gospodarcze i społeczno-polityczne. Na przekór niektórym sądom trzeba stwierdzić, że „w szybko zmieniającym

${ }^{27}$ J. Mariański, Religia i Kościół w spoleczeństwie pluralistycznym. Polska lat dziewięćdziesiatych, Lublin 1993, s. 262.

${ }^{28}$ Tamże.

${ }^{29}$ Tamże.

${ }^{30}$ Tamże, s. 264.

${ }^{31}$ Por. R. Kamiński, Duszpasterstwo w spoleczeństwie pluralistycznym, Lublin 1997, s. 52. 
się społeczeństwie polskim ewangelizacyjna obecność Kościoła staje się coraz bardziej potrzebna, nieodzowna i decydująca, a pole jego działania w pewnym sensie jeszcze się poszerza. Nie jest bowiem socjologiczną czy historyczną koniecznością, by życie publiczne w naszym kraju zostało zdominowane przez ideologię obywatelską z nieokreślonymi treściami religijnymi lub w ogóle bez nich"32. W zaistniałej po 1989 r. sytuacji w Polsce, nowa ewangelizacja wymaga systematycznego uwalniania się Kościoła od prowadzenia działalności zastępczej i skoncentrowania się na podstawowej działalności religijnej. Jest to szczególne wyzwanie w chwili, gdy część duchowieństwa i świeckich wiernych zaczyna widzieć przyszłość Kościoła w nowym przymierzu ołtarza z tronem. Kształtująca się w tych kręgach nowa, świecka soteriologia, w której zbawicielem nie jest Jezus Chrystus, tylko rządząca partia, paraliżuje w licznych sytuacjach wypełnianie przez Kościół właściwej mu misji prorockiej wobec społeczeństwa. Tymczasem „Kościół musi pozostać wierny swojej funkcji krytyczno-profetycznej, w ramach której akcentuje się konieczny związek wolności z prawdą i prawem moralnym. Może on i powinien ukazywać, że wartości samorealizacyjne i wartości religijne nie muszą się wzajemnie blokować, że jest możliwa synteza gwarantująca ich wzmocnienie w każdym kierunku, że to, co jest rzeczywiście cenne w tradycji, da się pogodzić z dobrze rozumianą nowoczesnością" ${ }^{33}$.

W kontekście wyzwań pluralizmu społeczno-kulturowego, wobec których staje polskie duszpasterstwo, podkreślić należy rolę parafii. Badania socjologiczne wskazują na to, że ,większość badanych dorosłych katolików zna swoją parafię i z nią się identyfikuje. Inaczej identyfikują się z parafią katolicy, którzy stanowią jej grupę podstawową, u których wiara kształtuje cały sens ich życia, inaczej katolicy przeciętni, uczestniczący mniej lub bardziej regularnie $\mathrm{w}$ niedzielnej liturgii $[\ldots]$ oraz jeszcze inaczej katolicy marginalni i nominalni" 34 . W aktualnej sytuacji, zwłaszcza w wielkich miastach, można zauważyć osłabienie sił społecznych konsolidujących parafię jako wspólnotę lokalną i atomizację życia parafialnego.

Ponieważ parafia terytorialna pozostaje ciągle podstawowym miejscem urzeczywistniania Kościoła jako faktu, wobec pojawiających się trudności, podkreśla się jej wspólnotowy charakter, ukazując ją jako wspólnotę wspólnot, czyli powiązaną siecią wzajemnych więzi grup, tworzących parafialną społeczność. Właśnie takie „uzupełnienie” struktury parafialnej sprawia, że - jak zwracał na to uwagę Jan Paweł II - „Ewangelia wciąż wydaje owoce we wspólnotach parafialnych, wśród osób konsekrowanych, w stowarzysze-

\footnotetext{
${ }^{32}$ J. Mariański, Religia i Kościót w społeczeństwie..., s. 268-269.

${ }^{33}$ Tamże, s. 270.

${ }^{34}$ J. Mariański, Katolicyzm polski..., s. 182-183.
} 
niach laikatu, w grupach modlitewnych i apostolskich, w różnych wspólnotach młodzieżowych, jak również poprzez nowe ruchy i dzieła kościelne i ich rozpowszechnianie się [...]. Dziś jeszcze w Europie, tak w krajach postkomunistycznych, jak i na Zachodzie, parafia - choć potrzebuje ciągłej odnowy - nadal ma do spełnienia i spełnia swoje niezbędne, bardzo aktualne posłannictwo w wymiarze duszpasterskim i eklezjalnym. Nadal potrafi ona dawać wiernym możliwość rzeczywistego prowadzenia życia chrześcijańskiego. Jest wciąż miejscem autentycznej humanizacji i socjalizacji, zarówno w bezimiennym i samotnym tłumie wielkich współczesnych miast, jak na słabo zaludnionych obszarach wiejskich" 35 .

W nowych warunkach społeczno-kulturowych proponuje się niekiedy dwa uzupełniające się kierunki działalności duszpasterskiej w ramach parafii. Jeden z nich ,zakłada utrwalenie związku wspólnoty parafialnej z lokalną strukturą społeczną tam, gdzie to jest tylko możliwe - aby umożliwić socjalizację wiary, która może stać się bardzo dobrym fundamentem dla procesu inicjacji”. Drugi, który odnosi się do nowej struktury społecznej charakterystycznej dla miasta, gdzie powiązania są o wiele słabsze, a parafian cechuje duża mobilność, zakłada uwzględnienie tej specyfiki środowiska. Tutaj „duszpasterstwo musi się liczyć z nowym rytmem pracy w ciągu tygodnia, z konkurencyjnością pastoralną, z większymi niż w społeczeństwie tradycyjnym oczekiwaniami oraz świadomością możliwości wyboru między ofertami. Duszpasterstwo w epoce mobilności musi być inne niż to, które było odpowiednie dla stabilnej kultury agrarnej, a potem kultury robotniczej" 36 .

Podkreśla się również konieczność zwrócenia uwagi „na społeczny wymiar wiary, na uczestniczenie w życiu wspólnoty parafialnej jako przejawu osobistej i dojrzałej wiary, nastawionej na ewangelizację. Oznacza to w istocie próbę przezwyciężenia deficytu dialogu jako zasady kierującej stosunkami wewnątrzkościelnymi, a także potrzebę kontaktów międzyosobowych, nacechowanych zaufaniem i współodpowiedzialnością w ramach wspólnoty parafialnej, łącznie z prawem do krytyki i stawiania niewygodnych pytań”37.

Wreszcie na koniec, nie sposób nie zauważyć, że w sytuacji szerzącego się relatywizmu moralnego, charakteryzującego pluralizm związany z równoległym funkcjonowaniem różnych systemów wartości, kiedy orędzie ewangeliczne z coraz większym trudem przenika kulturę społeczeństwa, wpływając na jego sposób myślenia i kształtowania kryteriów oraz norm postępowania, potrzeba przede wszystkim dogłębnej ewangelizacji samego świata i Kościo-

${ }^{35}$ Jan Paweł II, Adhortacja apostolska Ecclesia in Europa, Watykan 2003, pkt 15, s. 20-21.

${ }^{36}$ A. Draguła, Polscy wierzący poganie. Ratzinger czytany po 60 latach, „Więź”, nr 1 (671), 2018, s. 142-143.

${ }^{37}$ J. Mariański, Katolicyzm polski..., s. 247. 
ła. Wszystko wskazuje na to, że prowadząc to dzieło Kościół „będzie musiał częściej odwoływać się do moralności miłości i przebaczenia niż moralności przykazań i zakazów oraz posługiwać się częściej językiem pozytywno-afirmującym niż językiem karcąco-negatywnym"38. Będzie też musiał bardziej zwrócić uwagę na ludzi duchowo zagubionych, którzy po przeobrażeniach społeczno-politycznych znaleźli się pośród jego członków. Zainteresowani są oni odkryciem na nowo swego miejsca w kościelnej wspólnocie, oczekując od niej nie tyle moralnych wskazówek, co nade wszystko leczenia korzeni duszy. Wielokrotnie mieli już okazję dobrze poznać siłę moralną Kościoła, teraz zaś potrzebują ukazania im nade wszystko jego siły uzdrawiającej.

Ostatecznie poszukiwanie nowych form i sposobów przepajania duchem Ewangelii rzeczywistości społeczno-kulturowej, winno prowadzić do stworzenia fundamentu ,pod nową trwałą syntezę życia chrześcijańskiego”. Wymagać to będzie stałego wychowywania i kształtowania dojrzałych chrześcijan oraz świadectwa ,samych chrześcijan w życiu codziennym, także wobec tych, którzy przyglądają się z oddali, nierzadko ze sceptycyzmem, czy wręcz niechęcią"39. Mimo wszystkich niepokojów i lęków, często uzasadnionych, „społeczeństwo pluralistyczne nie niszczy religii, ale zmienia jej rolę w społeczeństwie. Dla wierzących jest to ustawiczne wyzwanie do ponownego odkrywania korzeni swojej wiary, do duchowej odnowy, do świadczenia o wierze we wszystkich środowiskach społecznych i dziedzinach życia, w których chrześcijanie są obecni”" ${ }^{40}$.

\author{
CHURCH MINISTRY IN POLAND IN THE FACE \\ OF INCREASING SOCIAL AND CULTURAL PLURALISM
}

\title{
Summary
}

The progressive social and cultural pluralism in Poland remains a significant challenge for the pastoral work of the Church. Its origins could already be seen in the late 1970s, when Poland was still under the leadership of the Communist Party. The article discusses the ongoing process of social and cultural pluralism and the consequences that result from it, for the pastoral ministry of the Church in Poland. The author tries to describe this process and then introduces the main thoughts of the Church's teaching regarding the phenomenon in question. At the end, he formulates proposals that can become an impulse for pastoral ministry in Poland.

\footnotetext{
${ }^{38}$ J. Mariański, Religia i Kościót w społeczeństwie..., s. 273-274.

${ }^{39}$ Tamże, s. 275.

${ }^{40}$ Tamże.
} 
Słowa kluczowe: pluralizm społeczny, pluralizm kulturowy, duszpasterstwo Kościoła w Polsce

Keywords: social pluralism, cultural pluralism, pastoral ministry of the Church in Poland

\section{BIBLIOGRAFIA}

CBOS, Religijność Polaków i ocena sytuacji Kościoła katolickiego. Komunikat z badań nr 147/ 2018 (listopad 2018) - https://www.cbos.pl/SPISKOM.POL/2018/K_147_18.PDF [dostęp: 10.12.2018].

Draguła A., Polscy wierzacy poganie. Ratzinger czytany po 60 latach, „Więź”, nr 1 (671), 2018, s. 131-144.

Dreier H., Staat ohne Gott. Religion in der säkularen Moderne, Verlag C.H. Beck, München 2018.

Drożdż B., Przygoda W., Pluralizm społeczno-kulturowy, [w:] Leksykon teologii pastoralnej, red. R. Kamiński, W. Przygoda, M. Fiałkowski, Towarzystwo Naukowe KUL, Lublin 2006, s. 623$-626$.

Dziri B., Dziri A. (Hg.), Aufbruch statt Abbruch. Religionen und Werte in einer pluralen Gesellschaft, Verlag Herder, Freiburg im Br. 2018.

Heinig H.M., Säkularer Staat - viele Religionen. Religionspolitische Herausforderungen der Gegenwart, Kreuz Verlag GmbH, Hamburg 2018.

Jan Paweł II, Adhortacja apostolska Ecclesia in Europa, Libreria Editrice Vaticana, Watykan 2003.

Jan Paweł II, Adhortacja apostolska Pastores dabo vobis, „L'Osservatore Romano”, wyd. polskie, nr 3-4, 1992, s. 4-63.

Jan Paweł II, Encyklika Evangelium vitae, Libreria Editrice Vaticana, Watykan 1995.

Jan Paweł II, Encyklika Fides et ratio, Libreria Editrice Vaticana, Watykan 1998.

Jan Paweł II, Orędzia na Światowy Dzień Migranta i Uchodźcy 1985-2005, opr. W. Necel, Hlondianum, Poznań 2009.

Kamiński R., Duszpasterstwo w społeczeństwie pluralistycznym, Instytut Teologii Pastoralnej KUL, seria: Teologia Praktyczna (1), Lublin 1997.

Kasperek A., Czy pluralizm religijny prowadzi do sekularyzacji? Socjologiczna glosa w sprawie polemiki Steve'a Bruce'a z Peterem Bergerem, [w:] Religijność i duchowość - dawne i nowe formy, red. M. Libiszowska-Żółtkowska i S. Grotowska, Nomos, Kraków 2010, s. 131-144.

Kongregacja Nauki Wiary, Nota doktrynalna o niektórych aspektach działalności i postępowania katolików w życiu politycznym, Watykan 2002 - http://www.vatican.va/roman_curia/congregations/cfaith/documents/rc_con_cfaith_doc_20021124_politica_pl.html [dostęp: 10.12.2018].

Mariański J., Katolicyzm polski $\overline{\text { Ciaglość }}$ i zmiana. Studium socjologiczne, Wydawnictwo WAM, Kraków 2011.

Mariański J., Kościót katolicki w Polsce a życie spoleczne. Studium socjologiczno-pastoralne, Wydawnictwo Gaudium, Lublin 2005.

Mariański J., Religia i Kościól między tradycją i ponowoczesnościq. Studium socjologiczne, Nomos, Kraków 1997.

Mariański J., Religia i Kościót w spoteczeństwie pluralistycznym. Polska lat dziewięćdziesiatych, Redakcja Wydawnictw KUL, Lublin 1993.

Pacewicz K., Polska globalnym liderem... w spadku religijności, „OKO.press”, 19 czerwca 2018 https://oko.press/polska-globalnym-liderem-w-spadku-religijnosci [dostęp: 20.09.2018].

Papieska Rada Iustitia et Pax, Kompendium nauki społecznej Kościoła, Wydawnictwo Jedność, Kielce 2005. 
Piwowarski W., Miejsce i rola Kościoła ludowego w spoleczeństwie polskim, „Przegląd Powszechny", nr 1-2, 1982, s. 61-76.

Piwowarski W., Pluralizm społeczno-kulturowy a religia, „Roczniki Nauk Socjologicznych, t. VIII (1980), s. 105-123.

Rhonheimer M., Christentum und säkularer Staat. Geschichte - Gegenwart - Zukunft, Verlag Herder, Freiburg im Br. 2014².

Stubenrauch B., Pluralismus statt Katholizität. Gott, das Christentum und die Religionen, Verlag Friedrich Pustet, Regensburg 2017.

Viertbauer K., Wegscheider F. (Hg.), Christliches Europa? Religiöser Pluralismus als theologische Herausforderung, Verlag Herder, Freiburg im Br. 2017.

Wagner J., Pluralizm, [w:] Stownik katolickiej nauki spolecznej, red. W. Piwowarski, Instytut Wydawniczy Pax, Wydawnictwo Polabra, Warszawa 1993, s. 130.

Zulehner P.M., Verbuntung. Kirchen im weltanschaulichen Pluralismus. Religion im Leben der Menschen 1970-2010, Schwabenverlag, Ostfildern 2011. 